\title{
Closing the methane mass balance for an old closed Danish landfill
}

\author{
Fjelsted, Lotte; Christensen, A. G.; Larsen, J. E.; Kjeldsen, Peter; Scheutz, Charlotte
}

Published in:

Waste Management

Link to article, DOI:

10.1016/j.wasman.2019.10.045

Publication date:

2020

Document Version

Peer reviewed version

Link back to DTU Orbit

Citation (APA):

Fjelsted, L., Christensen, A. G., Larsen, J. E., Kjeldsen, P., \& Scheutz, C. (2020). Closing the methane mass balance for an old closed Danish landfill. Waste Management, 102, 179-189.

https://doi.org/10.1016/j.wasman.2019.10.045

\section{General rights}

Copyright and moral rights for the publications made accessible in the public portal are retained by the authors and/or other copyright owners and it is a condition of accessing publications that users recognise and abide by the legal requirements associated with these rights.

- Users may download and print one copy of any publication from the public portal for the purpose of private study or research

- You may not further distribute the material or use it for any profit-making activity or commercial gain

- You may freely distribute the URL identifying the publication in the public portal

If you believe that this document breaches copyright please contact us providing details, and we will remove access to the work immediately and investigate your claim. 


\section{Closing the methane mass balance for an old closed Danish landfill}

2

Fjelsted, L. ${ }^{* \#}$, Christensen, A.G. , Larsen, J.E. , Kjeldsen, P. , Scheutz, C. *

${ }^{\#}$ Niras A/S, Sortemosevej 19, DK-3450 Allerød, Denmark

*Department of Environmental Engineering, Technical University of Denmark, DK-2800 Kgs. Lyngby, Denmark

Corresponding author:

Lotte Fjelsted.E-mail addresses: lfj@niras.dk

\section{Keywords}

Horizontal landfill gas migration; methane oxidation efficiencies; methane generation; gas recovery; tracer gas dispersion method; oxidation in landfill cover soil
Abstract
In this study, a methane $\left(\mathrm{CH}_{4}\right)$ mass balance was established for Hedeland landfill. $\mathrm{CH}_{4}$ generation rates were modelled using a multiphase first-order decay model (The Afvalzorg model) and determined at between 57 and $79 \mathrm{~kg} \mathrm{~h}^{-1}$. The $\mathrm{CH}_{4}$ emission rate was quantified at between 2 and $14 \mathrm{~kg} \mathrm{~h}^{-1}$, using the tracer gas dispersion method and the $\mathrm{CH}_{4}$ gas recovery efficiency was between 8 and $21 \%$. At three places along the perimeter of the landfill, gas remediation systems have been installed to protect the residential houses from any risk of migrating landfill gas. About $0.76 \mathrm{~kg} \mathrm{~h}^{-1}$ of $\mathrm{CH}_{4}$ was extracted from these three remediation systems. Using a carbon mass balance for the lateral migrating landfill gas showed a 
fractional oxidation of about $78 \%$, which corresponded to a $\mathrm{CH}_{4}$ flux of $3.5 \mathrm{~kg} \mathrm{~h}^{-1}$ from the three remediation systems, including the oxidised $\mathrm{CH}_{4}$. The total lateral $\mathrm{CH}_{4}$ flux (unoxidised) from the total landfill perimeter was estimated at between 6.9 and $10.4 \mathrm{~kg} \mathrm{~h}^{-1}$. $\mathrm{CH}_{4}$ oxidation efficiency in the landfill cover soil, determined from stable carbon isotope analyses, was found to be between $12 \%$ and $92 \%$. This resulted in an average $\mathrm{CH}_{4}$ oxidation rate of 32 $\mathrm{kg} \mathrm{h}^{-1}$, using an average $\mathrm{CH}_{4}$ emission rate of $8 \mathrm{~kg} \mathrm{~h}^{-1}$. $\mathrm{CH}_{4}$ surface screenings and surface flux measurements supported the hypothesis that oxidation efficiency was in the higher range and that oxidation could close the $\mathrm{CH}_{4}$ mass balance.

\section{Introduction}

Landfilling waste containing organic matter will produce landfill gas (LFG), mainly in the forms of methane $\left(\mathrm{CH}_{4}\right)$ and carbon dioxide $\left(\mathrm{CO}_{2}\right)$. The greenhouse gas potential of $\mathrm{CH}_{4}$ is 28 times greater than $\mathrm{CO}_{2}$ over a 100 -year period (not considering climate feedback) (IPCC, 2014), but it can also be explosive when mixed with air and might pose a risk to humans living near landfills. LFG can migrate to nearby houses and create an explosive atmosphere in confined spaces (Christophersen and Kjeldsen, 2001; Franzidis et al., 2008; Kumar et al., 2018; Williams and Aitkenhead, 1991). Furthermore, not only are landfills significant sources of $\mathrm{CH}_{4}$ emissions into the atmosphere, but they are also a long-term sink for carbon, as a minimum of $50 \%$ of landfilled organic carbon is typically not converted into biogas carbon but remains in the landfill as lignin and cellulosic fractions, which decompose slowly (Bogner et al., 2008).

Methane generated in a landfill will have different pathways, as illustrated in Fig. 1. If

$\mathrm{CH}_{4}$ generation is significant, LFG can be collected and utilised for power and/or heat production, upgraded to biogas or flared for a thermal conversion to $\mathrm{CO}_{2}$ (Stegmann, 1996). 


\section{9}

Part of the LFG will migrate to the top cover, where it can be oxidised to $\mathrm{CO}_{2}$ by methanotrophic bacteria in the cover soil. However, some of the migrating LFG may also escape into the atmosphere without any oxidation and add to anthropogenic $\mathrm{CH}_{4}$ emission and accumulation in the atmosphere. LFG can also migrate laterally to surrounding areas, and finally some will be temporarily stored inside the landfill. This can be summarised in the following $\mathrm{CH}_{4}$ balance for a landfill (Bogner and Spokas, 1993) (with all units in mass time $1)$ :

$\mathrm{CH}_{4}$ generated $=\mathrm{CH}_{4}$ emitted $+\mathrm{CH}_{4}$ oxidised $+\mathrm{CH}_{4}$ recovered (flared or utilised) $+\mathrm{CH}_{4}$ migrated $+\Delta \mathrm{CH}_{4}$ storage

Often, the only well-known term is the amount of $\mathrm{CH}_{4}$ recovered, which is sometimes recorded based on flow and $\mathrm{CH}_{4}$ concentration measurements. Alternatively the amount of recovered $\mathrm{CH}_{4}$ can be calculated based on data (e.g. electricity produced) from the engine utilising the LFG. Generated $\mathrm{CH}_{4}$ is often modelled based on landfilled waste amounts and waste compositions (Mou et al., 2015a), using different models for LFG generation (e.g. IPCC (IPCC, 2006) and Afvalzorg (Scharff et al., 2000; Scharff and Jacobs, 2006)), each of which has different advantages and disadvantages (Scharff and Jacobs, 2006).

Cracks and fissures in the top cover of the landfill and installations, such as leachate wells, can highly influence the magnitude of LFG emission. Also, the atmospheric pressure gradient will influence emissions (Rees-White et al., 2019; Xu et al., 2014). The emission of $\mathrm{CH}_{4}$ can be quantified by using either remote methods, such as tracer gas dispersion, DIAL (Differential Absorption LiDAR) or radial plume mapping (e.g. Babilotte et al., 2010; Goldsmith et al., 2012; Mønster et al., 2015, 2014), or surface-based point measurements (e.g. 
flux chamber measurements) that integrate total emissions (Mønster et al., 2019; Scheutz et al., 2009).

Potential $\mathrm{CH}_{4}$ oxidation in the cover soil is influenced by the load of $\mathrm{CH}_{4}$ to the cover, and soil conditions. $\mathrm{CH}_{4}$ oxidised in the top cover can be estimated by measuring the fractionation of stable carbon isotopes in upwind samples and in the downwind plume, as methanotrophs prefers ${ }^{12} \mathrm{C}$ over ${ }^{13} \mathrm{C}$ (Börjesson et al., 2001; Chanton et al., 1999; Liptay et al., 1998).

The lateral $\mathrm{CH}_{4}$ migration is influenced by different factors such as atmospheric conditions, the conditions of the bottom and side liners and the soil layers surrounding the landfill (Christophersen et al., 2001; Christophersen and Kjeldsen, 2001; Williams et al., 1999). Lateral migration is often calculated from diffusion through the bottom and side liners, under the assumption that the liner has not been compromised (Aghdam et al., 2018; Spokas et al., 2006). However, with a compromised liner, lateral migration can increase significantly, due to advective flow through cracks in the liner.

Change in $\mathrm{CH}_{4}$ storage inside the landfill is probably the most difficult term to quantify. It can be calculated from changes in $\mathrm{CH}_{4}$ concentration inside the landfill, the gas filled porosity of the waste body and the total landfill volume (Spokas et al., 2006). Changes in $\mathrm{CH}_{4}$ storage are affected by many factors, such as fluctuations in the leachate level in the landfill, changes in void space from the decomposition of waste, compaction and settlement, changes in extraction efficiency and in the short term from changes in atmospheric pressure (Spokas et al., 2006).

The objective of this study was to establish a $\mathrm{CH}_{4}$ mass balance for an old closed Danish landfill, namely Hedeland landfill. Lateral LFG migration and $\mathrm{CH}_{4}$ emissions have been investigated for many years at Hedeland landfill, and the large amount of collected data 
has been used to evaluate the different terms in a $\mathrm{CH}_{4}$ mass balance and close this balance. $\mathrm{A}$ number of new site investigation methods were applied including vertical drilling and gas monitoring, whole-site $\mathrm{CH}_{4}$ emission measurements and stable carbon isotopic analysis, to quantify $\mathrm{CH}_{4}$ oxidation. The landfill site has neighbours less than $100 \mathrm{~m}$ away from the perimeter, and lateral gas migration is a potential risk. Therefore gas is collected outside the perimeter and vented into the atmosphere. Any future remediation needs to consider both the risk to neighbours and the environmental impact in terms of climate change. The establishment of the site's $\mathrm{CH}_{4}$ mass balance forms the basis for designing and implementing a cost-efficient, long-term remediation strategy for the site.

\section{Materials and methods}

\subsection{Site description}

Hedeland landfill, near Roskilde, Denmark, is a controlled landfill with leachate and gas collection. The landfill covers an area of $115,000 \mathrm{~m}^{2}$, of which approximately $100,000 \mathrm{~m}^{2}$ has been used for landfilling. The site was established in 1979 and received approximately 2.9 million tonnes of mainly non-combustible waste and soil before after-care started in the middle of 2009. Hedeland was established in an old gravel pit and was constructed with bottom and side liners, which on the bottom and lower parts of the slopes consist of a polymer liner (no information about polymer type and thickness) on top of some refilled clay soil, and the upper parts of the slopes consist of at least one metre of clay, as shown in the cross-section diagram in Fig. 2. A leachate collection system was constructed with one pumping station draining leachate from all sections of the landfill. The side and bottom liners were not installed to prevent gas migration but to prevent leachate from entering the groundwater aquifer. In several places, the side liner was constructed without the polymer liner 
overlapping; instead, a horizontal clay connection was installed (see Fig. 2). The final top cover consists of at least $1 \mathrm{~m}$ of soil with no polymer liner. In one section of the landfill, several metres of soil have been deposited at the top. The maximum waste filling height was approximately $40 \mathrm{~m}$ and the average filling height around $25 \mathrm{~m}$.

The landfill has mainly received non-combustible waste with a low content of organic carbon. The main fractions consist of 'soil' (38\%), 'other waste' (36\%) not further specified in the available data, 'other non-combustible' (18\%), waste incineration residues ('bottom ash', 'fly ash' and 'flue gas cleaning residues') (6\%), 'bulky waste' (1\%) and 'waste water treatment sludge' $(1 \%)$. The remaining waste fractions make up less than $1 \%$ each.

The installed gas collection system consists of two parts. After establishing the permanent landfill cover, a gas collection system was installed in one section of the landfill with short vertical extraction wells (6-8 $\mathrm{m}$ deep). In another section of the landfill, a horizontal drainage system was installed on top of the waste, before the soil cover was installed. Knowledge about the landfill volume influenced by gas recovery is not available. The recovered gas is utilised in a duel-fuel diesel engine producing electricity.

Hedeland landfill is situated in a huge gravel deposit area. The gravel layer was originally between 10 and $15 \mathrm{~m}$ deep with an unsaturated zone of about $20 \mathrm{~m}$ deep. Within $100 \mathrm{~m}$ from the border of Hedeland landfill, seven residential houses are situated on top of a large unsaturated zone containing unsaturated gravel and sand, which is an easy route for lateral LFG migration and as such poses a risk for these residential houses. To stop the LFG from migrating to the houses, vertical remediation pumping wells and monitoring boreholes have been established outside of the landfilled waste.

\subsection{Methane generation modelling}



2000; Scharff and Jacobs, 2006), which utilises first-order degradation kinetics and can

147 accommodate eight waste categories with different biodegradable organic matter contents and degradation rates (rapid, moderate and slow) (Scharff \& Jacobs, 2006). The model requires waste input data on an annual basis, distributed in maximum eight categories. Since 1997, there has been a ban in Denmark on landfilling waste suitable for incineration. Consequently, modern landfills in the country contain low-organic waste, which is also the case for Hedeland landfill. The Afvalzorg model contains datasets for low-organic waste categories, and previous studies have shown that this model represents Danish landfills best (Aghdam et al., 2018; Mou et al., 2015b; 2015a; 2014; Scheutz et al., 2011b). The net landfilled waste amounts, and their distribution into different waste types, are given in Table SM1 in the Supplementary Material (SM).

As part of an ongoing investigation at the landfill, four deep gas extraction wells were installed in the waste body, as part of a pumping test conducted from 2015 to 2017 . The pumping tests were conducted to test if it was possible to prevent lateral migration of landfill gas to neighbouring plots by extracting gas in the waste body in the areas where lateral gas migration were observed. Locations of the four gas extraction wells are indicated in Fig. 3. Landfill gas was extracted from the waste with a pumping rate of $100-140 \mathrm{~m}^{3} \mathrm{~h}^{-1}$ for at least two months from each well (albeit from one well at a time). After two months of pumping, $\mathrm{CH}_{4}$ concentrations in the extracted gas seemed to have stabilised. Assuming that the stabilised $\mathrm{CH}_{4}$ concentration was an indication of the level of $\mathrm{CH}_{4}$ production in the waste body influenced by the extraction well, a $\mathrm{CH}_{4}$ generation rate for the total waste body was calculated based on the applied pump rates, $\mathrm{CH}_{4}$ concentrations measured in the extracted gas and an estimate of the influenced volume of the waste body from each extraction well using 
literature data. A maximum influence radius around LFG extraction wells of about $75 \mathrm{~m}$ was found in both Ham (1996) and Lofy (1996). A rule of thumb is that the horizontal influence is ten times that of the vertical influence (Ham, 1996). This is supported by an observation in a field study, where the vacuum from an extraction well was found to extend to a maximum 9 $\mathrm{m}$ below the bottom of the screen (Lofy, 1996). The gas-filled porosity of the waste body was assumed to be $0.1 \mathrm{~m}^{3} \mathrm{~m}^{-3}$ (Kjeldsen and Christensen, 2001), and it was further assumed that the influence of the extraction well was cylindrical around the screen - at a height that was indeed the height of the screen (in this case $4 \mathrm{~m}$ ) plus twice the vertical influence (where the vertical influence radius is one-tenth of the horizontal influence $(7.5 \mathrm{~m})$ on both sites of the screen) resulting in a vertical influence of $19 \mathrm{~m}$. From the estimated influence and $\mathrm{CH}_{4}$ generation rate of the four pumping tests, $\mathrm{a} \mathrm{CH}_{4}$ generation rate for the total waste body of Hedeland landfill was calculated. This estimated rate from the pump test served solely as a comparison to the modelled $\mathrm{CH}_{4}$ generation rate.

\subsection{Methane extraction and utilization}

Gas collected at the landfill is utilised in a dual-fuel engine, which uses diesel oil as its support fuel and produces electricity. The engine is run with the aim of maintaining stable electricity production and a constant consumption of diesel oil per produced $\mathrm{kWh}$. When production goes down because of a decrease in the $\mathrm{CH}_{4}$ content in the collected gas, the engine is stopped, until the level of $\mathrm{CH}_{4}$ is expected to have built up again (no information is available about time periods with no gas extraction). The amount of $\mathrm{CH}_{4}$ collected was estimated by the operator of the engine based on the amount of electricity produced and the amount of diesel oil used. The used conversion rate was $0.235 \mathrm{~m}^{3}$ of $\mathrm{CH}_{4} \mathrm{kWh}^{-1}$ including the 
diesel use and the efficiency of the engine. Based on this information, $\mathrm{CH}_{4}$ extraction rates were calculated as an annual average.

\subsection{Methane emission quantification}

Total landfill $\mathrm{CH}_{4}$ emissions were quantified using the tracer gas dispersion method, which combines the controlled release of tracer gas (acetylene $\left.\left(\mathrm{C}_{2} \mathrm{H}_{2}\right)\right)$ from the landfill with concentration measurements downwind of the landfill, using a mobile high-resolution analytical instrument (Mønster et al., 2015; 2014). The tracer gas dispersion method is based on the assumption that a tracer gas will disperse into the atmosphere in the same way as $\mathrm{CH}_{4}$ when emitted from the landfill (Mønster et al., 2015, 2014). The tracer method and the analytical equipment (based on Cavity Ring-Down Spectroscopy (CRDS)) are described in detail in Mønster et al., (2015; 2014) and Scheutz and Kjeldsen, 2019.

Table 1 provides an overview of measurement campaigns, showing dates, measuring distances, numbers of plume transects, wind speed and direction, numbers of tracer release points and tracer gas release rates for the $\mathrm{CH}_{4}$ emission quantifications conducted at Hedeland landfill. All four measurement campaigns were conducted under stable atmospheric conditions and were assumed to be representative of the average $\mathrm{CH}_{4}$ emission from the landfill.

\subsection{Changes in methane storage}

Any change in $\mathrm{CH}_{4}$ storage (short-term or long-term) can be calculated from a change in the average $\mathrm{CH}_{4}$ concentration in the waste, total landfill volume and the gas-filled porosity of the landfill (Spokas et al., 2006). 
Examples of processes causing short-term $\mathrm{CH}_{4}$ storage changes (hours or days) include fluctuations in atmospheric pressure or in LFG extraction rates. The change in $\mathrm{CH}_{4}$ storage was evaluated against a decrease in atmospheric pressure and a drop in $\mathrm{CH}_{4}$ concentration, simulating changes in the extraction rate using the ideal gas law and assuming an average gas temperature of $40^{\circ} \mathrm{C}$.

Changes in $\mathrm{CH}_{4}$ storage over the long-term (years to decades) could be caused by processes such as waste degradation and settlement causing changes in void space and the amount of material available for degradation and gas production. Long-term changes were not considered relevant, as the landfilled waste at Hedeland is very old (10 to 40 years) and no changes have been made to the landfill for many years since it was closed in 2009. Data for the mass balance thus represented a relative short time interval (about three years, from 2013 to 2015) in comparison to the lifetime of the landfill.

\subsection{Lateral methane migration}

To monitor the lateral migration of LFG, monitoring wells were installed and cased with two-metre screens placed in the upper part of the unsaturated gravel layer. In total, approximately 150 monitoring wells have been installed over the years, in order to monitor LFG content in the soil formation adjacent to the landfill. At three locations, remediation pumps have been installed on the wells, to pump any migrating LFG from the soil, before it reaches the residential houses. Gas compositions (content of $\mathrm{CH}_{4}, \mathrm{CO}_{2}$ and oxygen $\left(\mathrm{O}_{2}\right)$ ) at each screen have been monitored several times a year for many years, thereby providing detailed information about laterally migrating LFG.

From the installed gas remediation pumps, the flow rate of the pumps and the recorded concentrations of $\mathrm{CH}_{4}$ and $\mathrm{CO}_{2}$ in the off gas, the lateral fluxes of $\mathrm{CH}_{4}$ and $\mathrm{CO}_{2}$ coming from 
the landfill were estimated. Comparing the composition of the gas extracted from the remediation systems with landfill gas extracted from the gas wells installed in the waste indicated that a part of the $\mathrm{CH}_{4}$ was oxidised during the lateral migration of the landfill gas.

The soil compartment consisted of an unsaturated layer of mainly gravel and sand, thus it was assumed that the background level of $\mathrm{CO}_{2}$ in the soil compartment was zero (assuming insignificant soil respiration), and then the initial amount of $\mathrm{CH}_{4}$ migrating from the landfill, before oxidation, could be calculated from a carbon mass balance, using (Christophersen et al., 2001):

$$
\mathrm{J}_{\mathrm{CH} 4, \mathrm{LFG}}=\mathrm{C}_{\mathrm{CH} 4, \mathrm{LFG}} \cdot\left(\mathrm{C}_{\mathrm{CH} 4, \mathrm{LFG}}+\mathrm{C}_{\mathrm{CO} 2, \mathrm{LFG}}\right)^{-1} \cdot\left(\mathrm{J}_{\mathrm{CH} 4, \mathrm{RW}}+\mathrm{J}_{\mathrm{CO} 2, \mathrm{RW}}\right)
$$

Where $\mathrm{J}_{\mathrm{CH} 4, \mathrm{LFG}}$ is the flux of $\mathrm{CH}_{4}$ migrating laterally through the landfill bottom and side liner $\left(\mathrm{mol} \mathrm{h}^{-1}\right)$ before oxidation, $\mathrm{C}_{\mathrm{CH} 4, \mathrm{LFG}}$ and $\mathrm{C}_{\mathrm{CO} 2, \mathrm{LFG}}$ are the concentrations of $\mathrm{CH}_{4}$ and $\mathrm{CO}_{2}$ measured in the raw LFG (vol.\%), respectively and $\mathrm{J}_{\mathrm{CH} 4, \mathrm{RW}}$ and $\mathrm{J}_{\mathrm{CO} 2 \text {, RW }}$ are the fluxes of $\mathrm{CH}_{4}$ and $\mathrm{CO}_{2}$ in the remediation wells (RW) $\left(\mathrm{mol} \mathrm{h}^{-1}\right)$, respectively.

From the many years of investigations regarding laterally LFG migration, it is well documented where most of the lateral transport takes place. Unfortunately most of the transport occurs in the areas with residential houses and to protect the neighbours, remediation systems have been installed. The $\mathrm{CH}_{4}$ flux for the remaining landfill perimeter was estimated based on recorded $\mathrm{CH}_{4}$ concentrations in the monitoring wells located along the landfill perimeter. The perimeter of the landfill was divided in three groups: areas with remediation wells installed (corresponding to $25 \%$ of the total length of the perimeter), areas where $\mathrm{CH}_{4}$ was detected (>1 vol.\% $\mathrm{CH}_{4}$ (between 1-27 vol.\%)) in monitoring wells (not influenced by the extraction from the remediation wells) (25\% of the total length of the 
perimeter) and areas where no or very low $\mathrm{CH}_{4}$ concentrations was detected $\left(<1\right.$ vol. $\left.\% \mathrm{CH}_{4}\right)$ ( $50 \%$ of the total length of perimeter) (see Fig. 3). To assess a maximum and minimum $\mathrm{CH}_{4}$ flux two approaches were used. The maximum flux of migrating $\mathrm{CH}_{4}$ from the whole landfill perimeter, was estimated based on the assumption that the flux in areas where $\mathrm{CH}_{4}$ was detected was the same as the flux detected in the areas with remediation systems, while it was assumed to be half in the areas where no $\mathrm{CH}_{4}$ was detected (worst case, see Eq. 3). For estimating a minimum flux, the total flux of laterally migrating $\mathrm{CH}_{4}$ was calculated based on the assumption that the flux in the areas where $\mathrm{CH}_{4}$ was detected was half of the flux detected in the areas with remediation systems and only $25 \%$ in the areas where no $\mathrm{CH}_{4}$ was detected (see Eq. 4). It should be noted, that a concentration of $\mathrm{CH}_{4}$ below detection is not equal to no flux of LFG, due to oxidation of $\mathrm{CH}_{4}$ in the soil compartment. The total maximum and

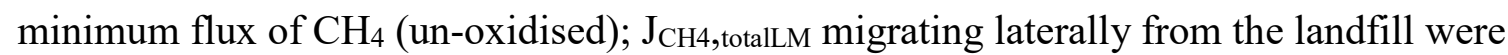
given by:

$$
\begin{aligned}
& \mathrm{J}_{\mathrm{CH} 4, \text { totalLM, max }}=\mathrm{J}_{\mathrm{CH} 4, \mathrm{LFG}}+\mathrm{J}_{\mathrm{CH} 4, \mathrm{LFG}}+2 \cdot 0.5 \cdot \mathrm{J}_{\mathrm{CH} 4, \mathrm{LFG}}=3 \cdot \mathrm{J}_{\mathrm{CH} 4, \mathrm{LFG}} \\
& \text { and } \\
& \mathrm{J}_{\mathrm{CH} 4, \text { totalLM, min }}=\mathrm{J}_{\mathrm{CH} 4, \mathrm{LFG}}+0.5 \cdot \mathrm{J}_{\mathrm{CH} 4, \mathrm{LFG}}+2 \cdot 0.25 \cdot \mathrm{J}_{\mathrm{CH} 4, \mathrm{LFG}}=2 \cdot \mathrm{J}_{\mathrm{CH} 4, \mathrm{LFG}}
\end{aligned}
$$
an average flux calculated as the average of the two.

The $\mathrm{CH}_{4}$ flux was thus assumed to range between the minimum and maximum flux with

\subsection{Methane oxidation potential in the cover soil}

The $\mathrm{CH}_{4}$ oxidation potential in landfill cover soil can be estimated based on the analysis of the stable ${ }^{13} \mathrm{C}$ isotope in upwind, downwind and raw gas samples (Chanton et al., 1999). 
287 The method is based on methanotrophic bacteria's preference for oxidising ${ }^{12} \mathrm{C}$ over ${ }^{13} \mathrm{C}$, so

$288 \mathrm{CH}_{4}$ becomes ${ }^{13} \mathrm{C}$-enriched after exposure to methanotrophs (for a detailed description of the

289 method, see e.g. Börjesson et al., 2007; Chanton and Liptay, 2000; Chanton et al., 2008, 1999; Liptay et al., 1998).

The $\mathrm{CH}_{4}$ oxidation rate can be calculated from the $\mathrm{CH}_{4}$ emission rate and the fraction of $\mathrm{CH}_{4}$ oxidised in the cover soil, $\mathrm{f}_{\text {ox,cover, }}$ using the following equation (Börjesson et al., 2007; Scheutz et al., 2011a):

$$
\mathrm{MO}=\mathrm{f}_{\mathrm{ox}, \text { cover }} \cdot \mathrm{E} \cdot\left(1-\mathrm{f}_{\mathrm{ox}}\right)^{-1}
$$

where $\mathrm{MO}$ is the $\mathrm{CH}_{4}$ oxidation rate $\left(\mathrm{kg} \mathrm{h}^{-1}\right), \mathrm{f}_{\mathrm{ox}}$ is the fraction of $\mathrm{CH}_{4}$ oxidised (\%) and $\mathrm{E}$ is the $\mathrm{CH}_{4}$ emission rate $\left(\mathrm{kg} \mathrm{h}^{-1}\right)$. Next, $\mathrm{f}_{\mathrm{ox}, \text { cover }}$ can be calculated from (Börjesson et al., 2007; Chanton et al., 1999):

$$
\mathrm{f}_{\mathrm{ox}, \mathrm{cover}}=\left(\delta_{\text {excess }}-\delta_{\mathrm{A}}\right)\left(1000\left(\alpha_{\mathrm{ox}}-\alpha_{\text {trans }}\right)\right)^{-1}
$$

where $\delta_{\text {excess }}$ is the excess of $\delta^{13} \mathrm{C}$ in the downwind plume, corrected for the upwind or background samples, $\delta_{\mathrm{A}}$ is the carbon isotopic content of raw gas $\mathrm{CH}_{4}, \alpha_{\mathrm{ox}}$ is the isotope fractionation factor related to $\mathrm{CH}_{4}$ oxidation by the landfill cover soil and $\alpha_{\text {trans }}$ is the isotope fractionation factor related to the transportation of gas through the cover soil. Five raw gas samples were collected from both monitoring wells in the waste body of the landfill and from the gas extraction system. Downwind gas samples were collected in the plume, using CRDS to identify the plume. Three soil cover samples were collected from 10 cm below the surface and used to determine $\alpha_{\mathrm{ox}}$ by incubation in the laboratory. The samples 
were incubated at $22^{\circ} \mathrm{C}$, following which gas samples were collected from the incubation bottles to analyse carbon isotope fractionation. The specific incubation test is described in more detail in Aghdam et al. (2018). All gas samples were analysed at Florida State University. Upwind of Hedeland landfill is another old landfill, which influences the fractionation of upwind samples from Hedeland, due to oxidation in its cover. As a result, fractionation $\left(\mathrm{\delta CH}_{4}\right)$ was obtained from another Danish landfill with upwind samples from the sea, as described in Aghdam et al. (2018).

\section{Results and discussion}

The years 2013-2015 were selected for the $\mathrm{CH}_{4}$ balance, as these provided the most complete dataset. The $\mathrm{CH}_{4}$ mass balance is given as an average for these three years.

\subsection{Methane generation modelling}

The result of the modelled $\mathrm{CH}_{4}$ generation over the lifetime of the landfill can be seen in Fig. 4. The generation peaked in 1989-1991 and has decreased since, albeit with a small increase again in 2006-2010, where the annual landfilled waste amounts increased significantly before waste disposal was terminated in the middle of 2009. Gas generation was modelled at between 57 and $79 \mathrm{~kg} \mathrm{~h}^{-1}$ in the period 2013-2015, with an average of $67 \pm 8.6 \mathrm{~kg}$ $\mathrm{h}^{-1}$ (average of maximum and minimum generation rates for the three years \pm the standard deviation (STD)) $\mathrm{CH}_{4}$ generation modelling was uncertain, as knowledge about the exact waste composition was limited. The main fractions of landfilled waste were unspecified or categorised in waste types, with no possibility of identifying potential biodegradable carbon content. Table SM1 and Table SM2 in the SM show the annual landfilled waste amounts 
distributed in Afvalzorg waste categories and the translation of Danish waste categories and fractions to Afvalzorg waste categories, respectively.

In addition, $\mathrm{CH}_{4}$ generation was estimated based on data from the pumping tests from four gas extraction wells in the waste body. Pumping rates and $\mathrm{CH}_{4}$ concentrations in the extracted gas after stabilisation showed $\mathrm{CH}_{4}$ generation rates of approximately $6,11,21$ and $28 \mathrm{~kg} \mathrm{~h}^{-1}$ for each of the four extraction wells, respectively. Summarising the $\mathrm{CH}_{4}$ generation rates from these tests gave a total $\mathrm{CH}_{4}$ generation rate of $66 \mathrm{~kg} \mathrm{~h}^{-1}$ from the four extraction wells. Using a radius of influence of $75 \mathrm{~m}$ and a vertical influence height of $19 \mathrm{~m}$, coverage of the total landfill body from the four pumping tests was estimated at about $71 \%$. Assuming that the $\mathrm{CH}_{4}$ generation rate was the same in the whole waste body, this corresponds to a total generation rate of $92 \mathrm{~kg} \mathrm{~h}^{-1}$, based on the pumping tests. The assumed influence radius of 75 $\mathrm{m}$ was found valid based on observed concentration response curves in monitoring wells located about 65-75 $\mathrm{m}$ from one of the four wells (well A2 in Fig. 3) used in the pumping tests. Data from the three other pumping test wells, though, were not as clear about the influence radius. There were no monitoring wells installed in the waste body inside the expected influence radius of these extraction wells (wells A7, A8 and A11 in Fig. 3), thus observations were only possible in monitoring wells located outside the waste body. However, during extraction no responses were observed in the nearest monitoring wells located about $40 \mathrm{~m}$ to $60 \mathrm{~m}$ from an extraction well. This could indicate that the radius of influence could be lower than $40 \mathrm{~m}$ for these wells. Assuming that only one of the four pumping tests reached the maximum estimated influence, and the three remaining pumping tests only reached half of the maximum, then $66 \mathrm{~kg} \mathrm{~h}^{-1}$ corresponds to $44 \%$ of the total landfill volume, in which case the total $\mathrm{CH}_{4}$ generation rate would then be $148 \mathrm{~kg} \mathrm{~h}^{-1}$, assuming the same generation rate for the total volume. 
Both the modelled $\mathrm{CH}_{4}$ generation rate and the $\mathrm{CH}_{4}$ generation rate estimated from the pumping tests included a number of assumptions (e.g. deposited waste fractions, distribution in waste categories, carbon contents and degradation rates, influenced landfill volume from pumps, no overlap of influence from the four pumps, total gas-filled landfill volume). Both methods however, produced reasonable comparable results, thus supporting the findings and reducing some of the uncertainty. The modelled generation rate was used as the basis for the mass balance.

Mou et al. (2015a) compared modelled $\mathrm{CH}_{4}$ generation rates, using the Afvalzorg model with standard values and a revised model using site-specific values for biochemical $\mathrm{CH}_{4}$ potential (BMP) and the $\mathrm{CH}_{4}$ generation rate constant (k-value) at four Danish landfills. They found that the Afvalzorg model using standard values overestimated the generation rate compared to field measurements using a $\mathrm{CH}_{4}$ balance approach (considering $\mathrm{CH}_{4}$ measured using the tracer gas dispersion method, recorded gas recovery rates and assuming oxidation of $10 \%$ of the emission rate), whereas using a revised model gave more comparable results.

Other studies at Danish landfills, comparable to Hedeland landfill in terms of age and accepted waste categories, showed $\mathrm{CH}_{4}$ generation rates using the Afvalzorg model comparable to $\mathrm{CH}_{4}$ generation rates obtained by establishment of $\mathrm{CH}_{4}$ mass balances based on field measurements (Aghdam et al., 2018; Scheutz et al., 2011b). Aghdam et al. (2018), for instance, found good agreement between estimated $\mathrm{CH}_{4}$ generation by using a mass balance approach (including gas recovery, oxidation estimated from stable carbon isotope analysis and $\mathrm{CH}_{4}$ emissions measured with the tracer gas dispersion method) and modelled using default values in Afvalzorg, compared to when site-specific data were used in the model. Scheutz et al. (2011b) compared gas generation rates obtained experimentally from waste sample incubations to modelled generation rates using the Afvalzorg and GasSim model. The results 
showed that application of the Afvalzorg model gave the generation rate most comparable to the experimental rates.

\subsection{Methane extraction and utilisation}

Data from the operator of the LFG utilisation engine show that the recovered $\mathrm{CH}_{4}$ rate varied between 6 and $12 \mathrm{~kg} \mathrm{~h}^{-1}$, from 2013 to 2015, with an average recovery rate of $9 \pm 2.9 \mathrm{~kg}$ $\mathrm{h}^{-1}$, which corresponds to a recovery efficiency of between 8 and $21 \%$ of the total $\mathrm{CH}_{4}$ generated $\left(67 \mathrm{~kg} \mathrm{~h}^{-1}\right)$. The recovery rate is based on the average annual recovered $\mathrm{CH}_{4}$. In three years, the amount of recovered $\mathrm{CH}_{4}$ varied by a factor of two, mainly because the engine was out for service in autumn 2014 and also had some longer stops in 2015, thereby significantly decreasing annual recovery for these years.

Recovery efficiency at Hedeland landfill is low compared to other studies (e.g. Aghdam et al., 2018; Börjesson et al., 2009; Spokas et al., 2006). At three French landfills, for instance, recovery efficiencies of over $80 \%$ were found at seven out of eight landfill sites with a recovery system, and four had recovery efficiencies above 90\% (Spokas et al., 2006).

Börjesson et al. (2009) studied seven Swedish landfills, where recovery rates from 32 to 1006 $\mathrm{kg} \mathrm{h}^{-1}$ were found, resulting in recovery efficiencies of $14-78 \%$. The low gas recovery efficiency at Hedeland landfill is due to relatively few - and shallow - gas recovery wells of only 6-8 $\mathrm{m}$ depth in a waste body at least $20 \mathrm{~m}$ deep.

\subsection{Methane emission quantification}

Four measuring campaigns were conducted over three years to measure total $\mathrm{CH}_{4}$ emissions from Hedeland landfill in different conditions. For details about these measurement conditions, see Table 1. The measured total $\mathrm{CH}_{4}$ emission rate ranged between 3.1 and 13.4 
$\mathrm{kg} \mathrm{h}^{-1}$, with an average of $8 \pm 4.1 \mathrm{~kg} \mathrm{~h}^{-1}$. Table 2 shows the results for all four measuring campaigns. The results of the emission quantifications show that operation of the gas recovery system highly influences the magnitude of $\mathrm{CH}_{4}$ emissions from the site. The longer the recovery was stopped prior to a measuring campaign, the higher the emission rate. The lowest emission rate of $3.1 \pm 0.7 \mathrm{~kg} \mathrm{~h}^{-1}$ was observed when gas recovery was in operation (recovering gas at an annual average rate of $12 \mathrm{~kg} \mathrm{~h}^{-1}$ ), while the highest emission rate of $13.4 \pm 0.8 \mathrm{~kg} \mathrm{~h}^{-1}$ was observed when the LFG recovery had been stopped for about 15 weeks prior to measurement. Measurements performed 2 and 8 weeks after LFG recovery had been stopped showed emission rates of $7.7 \pm 0.6 \mathrm{~kg} \mathrm{~h}^{-1}$ and $9.8 \pm 1.0 \mathrm{~kg} \mathrm{~h}^{-1}$, respectively. This suggests that there was some correlation between $\mathrm{CH}_{4}$ emission rates and $\mathrm{CH}_{4}$ recovery rates.

The emission rate at Hedeland landfill is lower than what has been found in previous studies at other Danish landfills. Quantifying $\mathrm{CH}_{4}$ emission rates from 15 Danish landfills, using the tracer gas dispersion method, showed emission rates ranging from 2.6 to $60.8 \mathrm{~kg} \mathrm{~h}^{-1}$, with Hedeland landfill in the lower half of the investigated sites (Mønster et al., 2015). Seven Swedish landfills investigated by Börjesson et al. (2009) showed emission rates between 12.8 and $441 \mathrm{~kg} \mathrm{~h}^{-1}$, with the emission rate from Hedeland landfill comparable to the landfill with the lowest emission rate.

\subsection{Changes in methane storage}

Changes in $\mathrm{CH}_{4}$ storage are affected by many factors, such as a change in the void space from waste decomposition, fluctuations in the leachate level, changes in gas recovery efficiencies or changes in temperature or atmospheric pressure. These factors result in fluctuations in the amount of $\mathrm{CH}_{4}$ gas in the gas-filled volume of the landfill. Two of these change factors were evaluated herein, namely atmospheric pressure and gas recovery 
efficiency, each resulting in a change in the $\mathrm{CH}_{4}$ level. A change in atmospheric pressure of \pm 1 mbar results in a variation in the mass of $\mathrm{CH}_{4}$ in the waste of $\pm 0.6 \mathrm{~g} \mathrm{CH}_{4} \mathrm{~m}^{-3} \mathrm{LFG} \mathrm{mbar}^{-1}$, using the ideal gas law and an average constant gas temperature of $40^{\circ} \mathrm{C}$. At Hedeland landfill, with an assumed gas-filled porosity of $0.1 \mathrm{~m}^{3} \mathrm{~m}^{-3}$, it resulted in a change in storage of $148 \mathrm{~kg}$, and with an average $\mathrm{CH}_{4}$ generation rate of $67 \mathrm{~kg} \mathrm{~h}^{-1}$, it corresponded to approximately two hours of $\mathrm{CH}_{4}$ generation per mbar change in atmospheric pressure. A change in recovery efficiency could result in a fluctuation in $\mathrm{CH}_{4}$ concentration in the gasfilled volume of the landfill. In the evaluation of the effect, a change of $1 \mathrm{vol} . \%$ in the $\mathrm{CH}_{4}$ concentration was assumed. From the total landfill volume, assumed gas-filled porosity and a change in the amount of $\mathrm{CH}_{4}$ of 1 vol.\% result in a fluctuation in $\mathrm{CH}_{4}$ storage of approximately $1600 \mathrm{~kg}$, corresponding to one day of $\mathrm{CH}_{4}$ generation per $1 \mathrm{vol} . \%$ change in $\mathrm{CH}_{4}$ concentration.

The two factors assessed showed that associated changes in $\mathrm{CH}_{4}$ storage would only be relevant on short-term (hours to days) and rather quickly be levelled out by the continuous gas generation. Most of the data (e.g. gas collected via the remediation system and gas collected via the gas collection system) used in the $\mathrm{CH}_{4}$ mass balance were measured continuously over longer time periods (months to years). Using average data in the mass balance is thus expected to level out any short-term changes. Whole site $\mathrm{CH}_{4}$ emission measurements were limited to four times. However, these were carried out during periods with stable atmospheric pressure and the emission rates should not be impacted by pressure changes. The results indicated that the $\mathrm{CH}_{4}$ emission rate was influenced by the gas collection (see section 3.3). However, as measurements were carried out during different operational conditions the average emission rate can be expected to be a reasonably representative estimate of the 
emission. In summary, the change in short-term storage was assessed as not being important for the overall $\mathrm{CH}_{4}$ mass balance at Hedeland landfill.

\subsection{Lateral methane migration}

Several years of investigations at Hedeland landfill identified lateral $\mathrm{CH}_{4}$ migration. Fig. 3 shows locations on the perimeter of the landfill where LFG has been detected in the unsaturated gravel layer. A concentration of $\mathrm{CH}_{4}$ above 1 vol. $\%$ has been defined as not acceptable by the competent authorities at Hedeland landfill. The red areas indicate where

$\mathrm{CH}_{4}$ concentrations above 1 vol.\% have been detected, while numbers in purple indicate the maximum concentration of $\mathrm{CH}_{4}$ measured in 2014. Based on data from the remediation pumping system, the total rate of $\mathrm{CH}_{4}$ captured by the three areas with a remediation system was determined at $0.76 \mathrm{~kg} \mathrm{~h}^{-1}$ in 2015 .

Data from the many monitoring wells at the landfill perimeter and at the neighbouring plots showed that for almost every measurement in the unsaturated zone around the landfill, the $\mathrm{CO}_{2}$ concentration was higher than the $\mathrm{CH}_{4}$ concentration - an indication of oxidation. From the carbon mass balance presented in Eq. 2 the flux of $\mathrm{CH}_{4}$ laterally migrating from the landfill to the three areas affected by the remediation system, including the oxidised $\mathrm{CH}_{4}$ was estimated to $3.5 \mathrm{~kg} \mathrm{~h}^{-1}$ of this was $2.7 \mathrm{~kg} \mathrm{~h}^{-1}$ oxidised. The total amount of $\mathrm{CH}_{4}$ laterally migrating from the whole perimeter of the landfill can be estimated using Eq. 3 and Eq. 4 and was determined at $10.4 \mathrm{~kg} \mathrm{~h}^{-1}$ and $6.9 \mathrm{~kg} \mathrm{~h}^{-1}$, respectively corresponding to $9-18 \%$ of the generated $\mathrm{CH}_{4}$ (assuming a $\mathrm{CH}_{4}$ generation rate of $57-79 \mathrm{~kg} \mathrm{~h}^{-1}$ ) giving an average lateral $\mathrm{CH}_{4}$ flux of $9 \pm 1.7 \mathrm{~kg} \mathrm{~h}^{-1}$. Details about raw LFG composition and the off gas composition from the remediation well is given in Table SM3 in SM. 
An oxidation rate of 0.1-0.3 $\mu \mathrm{g} \mathrm{CH}_{4} \mathrm{~g}^{-1} \mathrm{~h}^{-1}$ was found in a previous study, wherein

477 gravel samples from the unsaturated layer at Hedeland landfill were incubated in a batch test

(Pade and Paamand, 2008). This oxidation rate is relatively low in comparison to most $\mathrm{CH}_{4}$ oxidation rates observed in landfill cover soils $\left(0.0024-173 \mu \mathrm{g} \mathrm{CH}_{4} \mathrm{~g}^{-1} \mathrm{~h}^{-1}\right.$ from batch studies of landfill cover soils (Scheutz et al., 2009)); however, due to the large unsaturated zone (10$20 \mathrm{~m}$ deep), even a low oxidation rate can become significant. Using an average oxidation rate of $0.2 \mu \mathrm{g} \mathrm{CH}_{4} \mathrm{~g}^{-1} \mathrm{~h}^{-1}$, about $4 \mathrm{~kg} \mathrm{~h}^{-1}$ would be oxidised during $1 \mathrm{~m}$ of lateral transport in the unsaturated zone $\left(\sim 15,000 \mathrm{~m}^{3}\right.$ in total, assuming a $10 \mathrm{~m}$-deep unsaturated gravel zone and a $1500 \mathrm{~m}$ perimeter). This example assumes an even flow throughout the whole of the perimeter, which is not likely. However, considering the distance of 15-25 $\mathrm{m}$ from the liner to the screen of the monitoring wells used for remediation the example shows that landfill $\mathrm{CH}_{4}$ might undergo significant oxidation during transportation in the unsaturated zone. Results from the batch test run by Pade and Paamand (2008) also showed very low respiration, with $\mathrm{CO}_{2}$ production due to the respiration of only $0.0004 \mu \mathrm{g} \mathrm{CO}_{2} \mathrm{~g}^{-1} \mathrm{~h}^{-1}$, which validates the assumption of negligible soil respiration for the use of Eq. 2.

An LFG plume was found in the unsaturated zone, stretching more than $100 \mathrm{~m}$ from the boundary of an old landfill in the United Kingdom, situated in an abandoned sand/gravel pit (Williams et al., 1999). (Williams et al., 1999) found changes in stable hydrogen and carbon isotopes, and a reduction in the $\mathrm{CH}_{4}$ to $\mathrm{CO}_{2}$ ratio, clearly indicating microbial $\mathrm{CH}_{4}$ oxidation in the plume. Over a distance of less than $2.5 \mathrm{~m}, \mathrm{CH}_{4}$ concentrations decreased from approximately 20 vol. $\%$ to less than 1 vol. $\%$ at the eastern fringe of the plume. Two oxidation rates were found from the stable isotopes, namely a slow rate (half-life of $4.3-7.6$ years) in the centre of the plume, where oxygen was limited, and a faster rate (half-life of 0.76-1.21 
years) at the top of the plume and further away from the landfill (more than $60 \mathrm{~m}$ ) (Williams et al., 1999).

Lateral LFG migration has been studied intensively at a Danish landfill similar to Hedeland by Christophersen et al. (2001), Christophersen and Kjeldsen (2001) and Kjeldsen and Fischer (1995). These studies found that changes in atmospheric pressure were an important factor driving lateral LFG migration. Seasonal variations in $\mathrm{CH}_{4}$ and $\mathrm{CO}_{2}$ concentrations with, in general, higher $\mathrm{CO}_{2}$ surface fluxes in the summer were observed. On an annual basis, $89 \%$ of the laterally migrating LFG was oxidised (Christophersen et al., 2001).

Lateral migration of LFG can be caused by diffusion, advection or a combination thereof. Assuming diffusion solely through a non-compromised polymer liner, a $1.5 \mathrm{~mm}$ HDPE polymer liner with a partial pressure decrease over the liner of $1 \mathrm{~atm} \mathrm{CH}_{4}$ will allow $0.58 \mathrm{~cm}^{3} \mathrm{CH}_{4} \mathrm{~m}^{-2} \mathrm{~d}^{-1}$ to pass through (Lim, 1995; Pauly, 1989). Information about the used polymer type and thickness of the bottom and side liners at Hedeland landfill was not available. Assuming a HDPE liner of $1.5 \mathrm{~mm}$, the flux found at Hedeland landfill would result in a total diffusion of $\mathrm{CH}_{4}$ through the bottom and side liners of $0.0024 \mathrm{~kg} \mathrm{~h}^{-1}$, which is significantly lower than the migration rate found from the remediation systems, indicating that lateral migration at Hedeland is not caused purely by diffusion through a non-compromised liner. Results from the investigations along the perimeter of the landfill indicate that the side liner is compromised, possibly because it was constructed primarily to protect against seeping leachate and not specifically to prevent gas migration (Fig. 2), or because it has been damaged due to age and/or when the waste was landfilled.

\subsection{Methane oxidation potential in cover soil}



excess $\delta^{13} \mathrm{CH}_{4}$, anoxic $\mathrm{CH}_{4}$ and $\mathrm{CH}_{4}$ oxidation efficiency, $\mathrm{f}_{\mathrm{ox}}$, from the stable carbon isotopic analysis. The downwind concentration of $\mathrm{CH}_{4}$ ranged between 2.29 and $2.52 \mathrm{ppm}$, and $\delta^{13} \mathrm{CH}_{4}$ ranged between -46.13 and -48.63 . Compared to what had been found for other Danish landfills in Aghdam et al. (2018) and Scheutz et al. (2011), the $\delta^{13} \mathrm{CH}_{4}$ was a little higher. The five samples of anoxic $\mathrm{CH}_{4}$, namely $\delta_{\mathrm{A}}$, ranged between -51.46 and -58.00 , which was also a little higher than found in Aghdam et al. (2018) and Scheutz et al. (2011). The three different downwind samples result in $\mathrm{CH}_{4}$ oxidation efficiency in the cover soil of 12 , 27 and $92 \%$. In general, average efficiency is higher than the efficiencies found in Aghdam et al. (2018) and Scheutz et al. (2011), though they are comparable to what was found by Börjesson et al. (2007) at two closed Swedish landfills. efficiencies found in Table 3, the $\mathrm{CH}_{4}$ oxidation rate ranged between $1 \mathrm{~kg} \mathrm{~h}^{-1}$ and $92 \mathrm{~kg} \mathrm{~h}^{-1}$, resulting in an average oxidation rate of $32 \pm 52 \mathrm{~kg} \mathrm{~h}^{-1}$. and should therefore be interpreted with caution. First, the number of samples was limited,

542 and second, the stable carbon isotopic method holds a number of uncertainties (e.g. the 543 assumption that isotopic fractionation is only governed by bacteriological $\mathrm{CH}_{4}$ oxidation, and 544 gas transport through the cover is only governed by advection $\left.\left(\alpha_{\text {trans }}=1\right)\right)$ (Chanton et al., 2009; Gebert et al., 2011; Gebert and Streese-kleeberg, 2017). Recent field studies indicate that whole landfill site $\mathrm{CH}_{4}$ oxidation efficiencies are underestimated when stable carbon 
isotopic analysis is applied to upwind and downwind $\mathrm{CH}_{4}$ plume samples, and the method thus provides minimum oxidation efficiency for $\mathrm{CH}_{4}$ oxidation (Bourn et al., 2019; Sparrow et al., 2019).

The whole surface of the landfill was screened using a portable flame ionisation detector (FID) (TVA1000B, Thermo Scientific, USA), and relatively few hotspot areas were found with elevated concentrations of $\mathrm{CH}_{4}(\geq 25 \mathrm{ppm})$ at the surface, thereby indicating limited $\mathrm{CH}_{4}$ emissions. Results of the FID surface screening can be found in Fig. SM1 in SM. One of the hotspot areas with several elevated $\mathrm{CH}_{4}$ concentrations has been investigated in four flux emission measuring campaigns (see Fig. SM1 in SM for location), with surface $\mathrm{CH}_{4}$ fluxes only detected when atmospheric pressure decreased (Fjelsted et al., 2018). In that study, surface fluxes of $\mathrm{CH}_{4}$ and $\mathrm{CO}_{2}$ were measured at 100 points in a $100 \mathrm{~m}^{2}$ area, and the average $\mathrm{CH}_{4}$ and $\mathrm{CO}_{2}$ flux was reported at between 0 and $0.28 \mathrm{~mol} \mathrm{CH}_{4} \mathrm{~m}^{-2} \mathrm{~d}^{-1}$ (average of $0.08 \mathrm{~mol} \mathrm{CH}_{4} \mathrm{~m}^{-2} \mathrm{~d}^{-1}$ ) and 0 and $0.57 \mathrm{~mol} \mathrm{CO}_{2} \mathrm{~m}^{-2} \mathrm{~d}^{-1}$ (average of $0.38 \mathrm{~mol} \mathrm{CO}_{2} \mathrm{~m}^{-2} \mathrm{~d}^{-1}$ ). Using Eq. 2 with the measured fluxes results in a fractional $\mathrm{CH}_{4}$ oxidation in the landfill cover of $79 \%$, which is comparable to the highest efficiency found using the stable isotopic method. Many studies have been done through the years to determine the oxidation of LFG in cover soils, illustrating that the oxidation rate varies and depends on the cover type and conditions of the cover. In a review study by Chanton et al. (2009), 42 determinations of the fraction of oxidised $\mathrm{CH}_{4}$ gave an overall average of $36 \%$ (a standard error of $6 \%$ ) when including both laboratory column tests and field investigations. The highest oxidation efficiencies found in field measurements were $84 \%$ and $89 \%$ (the first from isotope fractionation, the latter from a $\mathrm{CH}_{4}$ and $\mathrm{CO}_{2}$ mass balance).

\subsection{Closing the methane mass balance}


$572 \mathrm{~kg} \mathrm{~h}^{-1}$ is summarised in Fig. 5. The modelled generated $\mathrm{CH}_{4}$ was $67 \pm 8.6 \mathrm{~kg} \mathrm{~h}^{-1}$, while $\mathrm{CH}_{4}$

573 emitted was $8 \pm 4.1 \mathrm{~kg} \mathrm{~h}^{-1}, \mathrm{CH}_{4}$ recovered was $9 \pm 2.9 \mathrm{~kg} \mathrm{~h}^{-1}$ and lateral $\mathrm{CH}_{4}$ migration was 9

$574 \pm 1.7 \mathrm{~kg} \mathrm{~h}^{-1}$ (including lateral oxidation). Individual terms in the mass balance have different

575 uncertainties, but oxidation in the landfill cover was considered the most uncertain of these

576 different terms. Using average rates for all terms other than oxidation in the cover leaves a

577 deficit in the $\mathrm{CH}_{4}$ mass balance of $42 \mathrm{~kg} \mathrm{~h}^{-1}$, corresponding to $63 \%$ of the generated $\mathrm{CH}_{4}$.

578 Several observations supported high $\mathrm{CH}_{4}$ oxidation in the landfill cover. Soil cover oxidation

579 was supported by stable carbon isotopic analysis, indicating fractional oxidation of 12 to $92 \%$.

580 Carbon mass balance for the molar surface flux emission of $\mathrm{CH}_{4}$ to $\mathrm{CO}_{2}$ showed signs of

581 fractional oxidation of about $79 \%$. A low total $\mathrm{CH}_{4}$ emission rate, found using the tracer gas

582 dispersion method and the relatively few hotspots with elevated $\mathrm{CH}_{4}$ concentration at the

583 surface, also supported a high oxidation rate in the landfill cover.

Oxidation of the mass balance deficit $\left(42 \mathrm{~kg} \mathrm{~h}^{-1}\right)$ corresponds to a load to the soil cover of $20 \mathrm{~g} \mathrm{~m}^{-2} \mathrm{~d}^{-1}$ (assuming half of the landfill surface area is active, which equates to 50,000 $\mathrm{m}^{2}$ ). This load is significantly lower than most of the oxidation rates found in a review of 24 column experiments simulating landfill cover soil with $\mathrm{CH}_{4}$ oxidation rates in the range between 22 and $230 \mathrm{~g} \mathrm{CH}_{4} \mathrm{~m}^{-2} \mathrm{~d}^{-1}$ (Scheutz et al., 2009). Moreover, Börjesson et al. (2007) found oxidation rates of 72-106 $\mathrm{kg} \mathrm{h}^{-1}$ at a closed landfill in Sweden containing household waste, but with an emission rate, recovery rate and generation rate significantly higher

591 compared to what was found for Hedeland landfill. All in all, the results from Hedeland landfill supported by $\mathrm{CH}_{4}$ oxidation rates reported in the scientific literature clearly show that 


\section{Conclusion and perspectives}

597

598

599

600

601

602

603

604

605

606

607

608

609

610

611

612

613

614

615

616

617

618

A methane $\left(\mathrm{CH}_{4}\right)$ mass balance was established for an old closed Danish landfill containing waste with a low organic carbon content. $\mathrm{CH}_{4}$ emissions, recovery and migration were estimated and compared to the modelled $\mathrm{CH}_{4}$ generation. The study showed that in average $37 \%$ of the generated $\mathrm{CH}_{4}\left(67 \mathrm{~kg} \mathrm{~h}^{-1}\right)$ was accounted for by emissions $(12 \%)$, recovery (13\%) and lateral migration (including lateral oxidation) (13\%). Several observations including stable carbon isotopic analysis, surface $\mathrm{CH}_{4}$ screenings and flux measurements supported a significant oxidation rate in the landfill cover soil, which could account for the deficit of $42 \mathrm{~kg} \mathrm{~h}^{-1}$ (corresponding to $63 \%$ of the generated $\mathrm{CH}_{4}$ being oxidized or $84 \%$ of the methane load to the cover soil). $\mathrm{CH}_{4}$ oxidation was unexpectedly high - much higher than the $10 \%$ of the cover load, which is suggested in the IPCC guideline for national inventory reporting.

Landfill bottom liners are constructed primarily with the aim of protecting groundwater and surroundings against seeping leachate, and they do not focus on protection against migrating LFG. Considering the $\mathrm{CH}_{4}$ mass balance helps in designing and developing a permanent, cost-efficient solution for LFG at the site that considers both the risk of migrating LFG for neighbours and the consequences of climate change from $\mathrm{CH}_{4}$ emissions. The relatively low recovery rate indicates that there is a potential for increasing gas recovery and utilisation, but this will require installing new and/or deeper extraction wells, which is an expensive undertaking. A thorough analysis of the economic and environmental impacts of increased recovery is required to determine the benefits in this regard. Off gas from the remediation system can be treated in a biofilter, which could also handle the dilute gas from the extraction system, when $\mathrm{CH}_{4}$ concentrations fall to a level where utilisation is no longer 
feasible. Moreover, the high oxidation rate in the cover could be utilised in the elimination of undesired emissions from the remediation system by re-infiltrating off gas from the remediation system in the wells already installed in the waste body.

\section{Acknowledgements}

The work presented herein was funded by an industrial $\mathrm{PhD}$ project hosted by Niras $\mathrm{A} / \mathrm{S}$ and The Technical University of Denmark (DTU). The PhD project was funded by the Innovation Fund Denmark (Project ref. no.: 4135-00011B). The authors wish to thank ARGO for providing access to Hedeland landfill and all the data from previous investigations at the site.

\section{Supplemental Material}

Supplemental material, with data on waste amounts, waste composition and the distribution of accepted waste categories into Afvalzorg categories, results of the surface screening, calculation of $\mathrm{CH}_{4}$ oxidation in lateral migrating $\mathrm{LFG}$, are available online. Calculation of the $\mathrm{CH}_{4}$ mass balance deficit using both modelled and estimated (from pumping tests) $\mathrm{CH}_{4}$ generation is also available online.

\section{References}

Aghdam, E.F., Fredenslund, A.M., Chanton, J., Kjeldsen, P., Scheutz, C., 2018. Determination of gas recovery efficiency at two Danish landfills by performing downwind methane measurements and stable carbon isotopic analysis. Waste Manag. 73, 220-229. https://doi.org/10.1016/j.wasman.2017.11.049

Babilotte, A., Lagier, T., Fiani, E., Taramini, V., 2010. Fugitive Methane Emissions from 
Landfills: Field Comparison of Five Methods on a French Landfill. J. Environ. Eng. 136, 777-784. https://doi.org/10.1061/(ASCE)EE.1943-7870.0000260

Bogner, J., Pipatti, R., Hashimoto, S., Diaz, C., Mareckova, K., Diaz, L., Kjeldsen, P., Monni, S., Faaij, A., Qingxian, G., Tianzhu, Z., Mohammed, A.A., Sutamihardja, R.T.M., Gregory, R., 2008. Mitigation of global greenhouse gas emissions from waste: Conclusions and strategies from the Intergovernmental Panel on Climate Change (IPCC) Fourth Assessment Report. Working Group III (Mitigation). Waste Manag. Res. Res. 26, 11-32. https://doi.org/10.1177/0734242X07088433

Bogner, J., Spokas, K., 1993. Landfill CH4: Rates, Fates, and Role in Global Carbon Cycle. Chemosphere 26, 369-386.

Börjesson, G., Chanton, J., Svensson, B.H., 2001. Methane oxidation in two Swedish landfill covers measured with carbon-13 to carbon-12 isotope ratios. J. Environ. Qual. 30, 369376. https://doi.org/10.2134/jeq2001.302369x

Börjesson, G., Samuelsson, J., Chanton, J., 2007. Methane oxidation in Swedish landfills quantified with the stable carbon isotope technique in combination with an optical method for emitted methane. Environ. Sci. Technol. 41, 6684-6690. https://doi.org/10.1021/es062735v

Börjesson, G., Samuelsson, J., Chanton, J., Adolfsson, R., Galle, B., Svensson, B.H., 2009. A national landfill methane budget for Sweden based on field measurements, and an evaluation of IPCC models. Tellus, Ser. B Chem. Phys. Meteorol. Tellus Ser. B Chem. Phys. Meteorol 61, 424-435. https://doi.org/10.1111/j.1600-0889.2008.00409.x

Bourn, M., Robinson, R., Innocenti, F., Scheutz, C., 2019. Regulating landfills using measured methane emissions: An English perspective. Waste Manag. 87, 860-869. 
667

668

669

670

671

672

673

674

675

676

677

678

679

680

681

682

683

684

685

686

687

688

Chanton, J., Liptay, K., 2000. Seasonal variation in methane oxidation in a landfill cover soil as determined by an in situ stable isotope technique. Global Biogeochem. Cycles 14, 5160. https://doi.org/10.1029/1999GB900087

Chanton, J.P., Powelson, D.K., Abichou, T., Fields, D., Green, R., 2008. Effect of temperature and oxidation rate on carbon-isotope fractionation during methane oxidation by landfill cover materials. Environ. Sci. Technol. 42, 7818-7823. https://doi.org/10.1021/es801221y

Chanton, J.P., Powelson, D.K., Green, R.B., 2009. Methane Oxidation in Landfill Cover Soils, is a 10\% Default Value Reasonable? J. Environ. Qual. 38, 654. https://doi.org/10.2134/jeq2008.0221

Chanton, J.P., Rutkowski, C.M., Mosher, B., 1999. Quantifying methane oxidation from landfills using stable isotope analysis of downwind plumes. Environ. Sci. Technol. 33, 3755-3760. https://doi.org/10.1021/es9904033

Christophersen, M., Kjeldsen, P., 2001. Lateral gas transport in soil adjacent to an old landfill: factors governing gas migration. Waste Manag. Res. 19, 579-594. https://doi.org/10.1177/0734242X0101900616

Christophersen, M., Kjeldsen, P., Holst, H., Chanton, J., 2001. Lateral gas transport in soil adjacent to an old landfill: factors governing emissions and methane oxidation. Waste Manag. Res. 19, 595-612. https://doi.org/10.1177/0734242X0101900616

Fjelsted, L., Christensen, A.G., Larsen, J.E., Kjeldsen, P., Scheutz, C., 2018. Assessment of a landfill methane emission screening method using an unmanned aerial vehicle mounted thermal infrared camera - A field study. Waste Manag. 
690

691

692

693

694

695

696

697

698

699

700

701

702

703

704

705

706

707

708

709

710

711

Franzidis, J.-P., Heroux, M., Nastev, M., Guy, C., 2008. Lateral migration and offsite surface emission of landfill gas at City of Montreal landfill site. Waste Manag. Res. 26, 121131. https://doi.org/10.1177/0734242X07085752

Gebert, J., Streblow, C., Knoblauch, C., Pfeiffer, E.M., 2011. Effect of gas transport on fractionation of carbon stable isotopes related to the microbial oxidation of methane in soils, in: Proceedings Sardinia 2011, Thirteenth International Waste Management and Landfill Symposium. S. Margherita di Pula, Cagliari, Italy. https://doi.org/10.1016/j.soilbio.2010.07.004.Marrero

Gebert, J., Streese-kleeberg, J., 2017. Coupling Stable Isotope Analysis with Gas Push-Pull Tests to Derive In Situ Values for the Fractionation Factor a. Soil Sci. Soc. Am. J. 81, 1107-1114. https://doi.org/10.2136/sssaj2016.11.0387

Goldsmith, C.D., Chanton, J., Abichou, T., Swan, N., Green, R., Hater, G., 2012. Methane emissions from 20 landfills across the United States using vertical radial plume mapping. J. Air Waste Manag. Assoc. 62, 183-197. https://doi.org/10.1080/10473289.2011.639480

Ham, R.K., 1996. 4.4 Field Testing for Evaluation of Landfill Gas Yields, in: Christensen, T.H., Cossu, R., Stegmann, R. (Eds.), Landfilling of Waste: Biogas. E \& FN Spon.

IPCC, 2014. Climate Change 2014: Synthesis Report. Contribution of Working Groups I, II and III to the Fifth Assessment Report of the Intergovernmental Panel on Climate Change.

IPCC, 2006. 2006 IPCC Guidelines for National Greenhouse Gas Inventories [WWW Document]. URL https://www.ipcc-nggip.iges.or.jp/public/2006gl/index.html (accessed 
713

Kjeldsen, P., Christensen, T.H., 2001. A simple model for the distribution and fate of organic chemicals in a landfill: MOCLA. Waste Manag. Res. 19, 201-216. https://doi.org/10.1177/0734242X0101900303

Kjeldsen, P., Fischer, E. V., 1995. Landfill gas migration - Field investigations at Skellingsted landfill, Denmark. Waste Manag. Res. 13, 467-484. https://doi.org/10.1016/S0734$242 X(05) 80025-4$

Kumar, A., Datta, M., Nema, A.K., Singh, R.K., Gurjar, B.R., 2018. Improved rating system for hazard assessment related to subsurface migration of landfill gas from municipal solid waste landfills and dumps. J. Hazardous, Toxic, Radioact. Waste 22, 1-10. https://doi.org/10.1061/(ASCE)HZ.2153-5515.0000393

Lim, K.T., 1995. Mega-molecular dynamics on highly parallel computers: Methods and applications. California Institute of Technology, Pasadena, California.

Liptay, K., Chanton, J., Czepiel, P., Mosher, B., 1998. Use of stable isotopes to determine methane oxidation in landfill cover soils. J. Geophys. Re 103, 8243-8250.

Lofy, R.J., 1996. 5.1 Zones of Vacuum Influence Surrounding Gas Extraction Wells, in: Christensen, T.H., Cossu, R., Stegmann, R. (Eds.), Landfilling of Waste: Biogas. E \& FN Spon.

Mønster, J., Kjeldsen, P., Scheutz, C., 2019. Methodologies for measuring fugitive methane emissions from landfills - A review. Waste Manag. 87, 835-859. https://doi.org/10.1016/j.wasman.2018.12.047

Mønster, J., Samuelsson, J., Kjeldsen, P., Scheutz, C., 2015. Quantification of methane 
emissions from 15 Danish landfills using the mobile tracer dispersion method. Waste Manag. 35, 177-186. https://doi.org/10.1016/j.wasman.2014.09.006

Mønster, J.G., Samuelsson, J., Kjeldsen, P., Rella, C.W., Scheutz, C., 2014. Quantifying methane emission from fugitive sources by combining tracer release and downwind measurements - A sensitivity analysis based on multiple field surveys. Waste Manag. 34, 1416-1428. https://doi.org/10.1016/j.wasman.2014.03.025

Mou, Z., Scheutz, C., Kjeldsen, P., 2015a. Evaluation and application of site-specific data to revise the first-order decay model for estimating landfill gas generation and emissions at Danish landfills. J. Air Waste Manage. Assoc. 65, 686-698. https://doi.org/10.1080/10962247.2015.1008653

Mou, Z., Scheutz, C., Kjeldsen, P., 2015b. Evaluating the methane generation rate constant (k value) of low-organic waste at Danish landfills. Waste Manag. 35, 170-176. https://doi.org/10.1016/j.wasman.2014.10.003

Mou, Z., Scheutz, C., Kjeldsen, P., 2014. Evaluating the biochemical methane potential (BMP) of low-organic waste at Danish landfills. Waste Manag. 34, 2251-2259. https://doi.org/10.1016/j.wasman.2014.06.025

Pade, D.M., Paamand, E.T., 2008. Afværge af gasspredning fra gammel losseplads Undersøgelser for lossepladsgas ved Hedebo Losseplads, Roskildevej 73. Technical University of Denmark.

Pauly, S., 1989. Permeability and Diffusion Data, in: Brandrup, J., Immergut, E.H. (Eds.), Polymer Handbook. Wiley, NY.

Rees-White, T.C., Mønster, J., Beaven, R.P., Scheutz, C., 2019. Measuring methane emissions from a UK landfill using the tracer dispersion method and the influence of 
operational and environmental factors. Waste Manag. 87, 870-882. https://doi.org/10.1016/j.wasman.2018.03.023

Scharff, H., Jacobs, J., 2006. Applying guidance for methane emission estimation for landfills. Waste Manag. 26, 417-429. https://doi.org/10.1016/j.wasman.2005.11.015

Scharff, H., Oonk, J., Hensen, A., 2000. Quantifying landfill gas emissions in the Netherlands - Definition study, Novem.

Scheutz, C., Fredenslund, A.M., Chanton, J., Pedersen, G.B., Kjeldsen, P., 2011a. Mitigation of methane emission from Fakse landfill using a biowindow system. Waste Manag. 31, 1018-28. https://doi.org/10.1016/j.wasman.2011.01.024

Scheutz, C., Fredenslund, A.M., Nedenskov, J., Samuelsson, J., Kjeldsen, P., 2011b. Gas production, composition and emission at a modern disposal site receiving waste with a low-organic content. Waste Manag. 31, 946-955. https://doi.org/10.1016/j.wasman.2010.10.021

Scheutz, C., Kjeldsen, P., 2019. Guidelines for landfill gas emission monitoring using the tracer gas dispersion method. Waste Manag. 85, 351-360. https://doi.org/10.1016/j.wasman.2018.12.048

Scheutz, C., Kjeldsen, P., Bogner, J.E., De Visscher, A., Gebert, J., Hilger, H.A., HuberHumer, M., Spokas, K., 2009. Microbial methane oxidation processes and technologies for mitigation of landfill gas emissions. Waste Manag. Res. 27, 409-455. https://doi.org/10.1177/0734242X09339325

Sparrow, K.J., Chanton, J.P., Green, R.B., Scheutz, C., Hater, G.R., Wilson, L.C., Abichou, T., 2019. Stable isotopic determination of methane oxidation: When smaller scales are better. Waste Manag. 97, 82-87. https://doi.org/10.1016/j.wasman.2019.07.032 
Spokas, K., Bogner, J., Chanton, J.P., Morcet, M., Aran, C., Graff, C., Golvan, Y.M.-L., Hebe, I., 2006. Methane mass balance at three landfill sites: What is the efficiency of capture by gas collection systems? Waste Manag. 26, 516-25. https://doi.org/10.1016/j.wasman.2005.07.021

Stegmann, Rainer, 1996. 1.2 Landfill Gas Utilization: An Overview, in: Christensen, T.H., Cossu, R., Stegmann, R. (Eds.), Landfilling of Waste: Biogas. E \& FN Spon, London, pp. 9-17.

Williams, G.M., Aitkenhead, N., 1991. Lessons from Loscoe: the uncontrolled migration of landfill gas. Q. J. Eng. Geol. 24, 191-207.

Williams, G.M., Ward, R.S., Noy, D.J., 1999. Dynamics of landfill gas migration in unconsolidated sands. Waste Manag. Res. 17, 327-342.

Xu, L., Lin, X., Amen, J., Welding, K., McDermitt, D., 2014. Impact of changes in barometric pressure on landfill methane emission. Global Biogeochem. Cycles 28, 679-695. https://doi.org/10.1002/2013GB004571 
796

797 Table 1. Overview of $\mathrm{CH}_{4}$ emission measurement campaigns conducted at Hedeland landfill, 798 using the tracer gas dispersion method.

\begin{tabular}{|c|c|c|c|c|}
\hline Date & $\begin{array}{c}\text { Measuring distance to } \\
\text { the landfill } \\
\text { [m] and total number } \\
\text { of plume transects } \\
\text { made (n) }\end{array}$ & $\begin{array}{l}\text { Avg. wind speed } \\
{\left[\mathrm{m} \mathrm{s}^{-1}\right] \text { and dominant }} \\
\text { direction }\end{array}$ & $\begin{array}{l}\text { Number of tracer gas } \\
\text { release points }\end{array}$ & $\begin{array}{c}\text { Total tracer gas } \\
\text { release rate } \\
{\left[\mathrm{kg} \mathrm{h}^{-1}\right]}\end{array}$ \\
\hline 14.05 .2013 & $\begin{array}{l}1000 \\
(18)\end{array}$ & $\begin{array}{l}5 \\
\mathrm{~S}\end{array}$ & 2 & 0.9 \\
\hline 21.05 .2014 & $\begin{array}{l}700 \\
(8)\end{array}$ & $\begin{array}{c}5.5 \\
\mathrm{E}-\mathrm{SE}\end{array}$ & 2 & 1.3 \\
\hline 27.11 .2014 & $\begin{array}{l}800 \\
(45)\end{array}$ & $\begin{array}{c}3 \\
\mathrm{SE}\end{array}$ & 3 & 1.4 \\
\hline 20.11 .2015 & $\begin{array}{l}1100 \text { and } 4000 \\
(11 \text { and } 10)\end{array}$ & $\begin{array}{c}2.3 \\
\mathrm{~N}-\mathrm{NE}\end{array}$ & 2 & 2.1 \\
\hline
\end{tabular}

799

800 
801 Table 2. Overview of the measurement campaigns quantifying whole-site $\mathrm{CH}_{4}$ emissions.

\begin{tabular}{ccccc}
\hline & 14-05-2013 & $\mathbf{2 1 - 0 5 - 2 0 1 4}$ & $\mathbf{2 7 - 1 1 - 2 0 1 4}$ & $\mathbf{2 0 - 1 1 - 2 0 1 5}$ \\
\hline $\begin{array}{c}\mathrm{CH}_{4} \mathrm{emission}_{\left[\mathrm{kg} \mathrm{h}^{-1}\right]} \\
\begin{array}{c}\text { Gas collection } \\
\text { on/off }\end{array}\end{array}$ & On & $7.7 \pm 0.6$ & $13.4 \pm 0.8$ & $9.8 \pm 1.0$ \\
$\begin{array}{c}\mathrm{CH} \text { recovery } \\
(\text { Annual average }) \\
{\left[\mathrm{kg} \mathrm{h} \mathrm{h}^{-1}\right]}\end{array}$ & 12 & $\begin{array}{c}\text { LFG recovery stopped } \\
\text { for two weeks prior to } \\
\text { measurement }\end{array}$ & $\begin{array}{c}\text { LFG recovery stopped } \\
\text { for 15 weeks prior to } \\
\text { measurement }\end{array}$ & $\begin{array}{c}\text { LFG stopped for } 8 \\
\text { weeks prior to } \\
\text { measurement }\end{array}$ \\
\hline
\end{tabular}

802

803 
804 Table 3. Results from the stable carbon isotope analysis. Three downwind samples were

805 analysed, and the results are presented in the table. Results from upwind samples and anoxic

$806 \mathrm{CH}_{4}$ are the average of three and five samples, respectively.

\begin{tabular}{|c|c|c|c|c|c|c|c|}
\hline $\begin{array}{l}\text { Sample } \\
\text { no. }\end{array}$ & $\begin{array}{l}\text { Downwind } \mathrm{CH}_{4} \\
\text { concentration } \\
\text { [ppmv] }\end{array}$ & $\begin{array}{l}\text { Downwind } \\
\mathrm{\delta} \mathrm{CH}_{4}\end{array}$ & $\begin{array}{l}\text { Upwind } \mathrm{CH}_{4} \\
\text { concentration } \\
{[p p m v]}\end{array}$ & $\begin{array}{l}\text { Upwind } \\
\delta 13 \mathrm{CH}_{4}\end{array}$ & $\begin{array}{l}\text { Excess } \\
\delta_{13 \mathrm{CH}} 4\end{array}$ & $\begin{array}{l}\text { Anoxic } \\
\mathrm{CH}_{4} ; \delta \mathrm{A}\end{array}$ & $f_{\text {fox }}$ \\
\hline 1 & 2.52 & -48.31 & 1.92 & -47.79 & -49.93 & -55.07 & 0.27 \\
\hline 2 & 2.30 & -46.13 & 1.92 & -47.79 & -37.85 & -55.07 & 0.92 \\
\hline 3 & 2.29 & -48.63 & 1.92 & -47.79 & -52.85 & -55.07 & 0.12 \\
\hline
\end{tabular}

${ }^{\text {a }}$ Data from Stige Ø (Aghdam et al., 2018). 


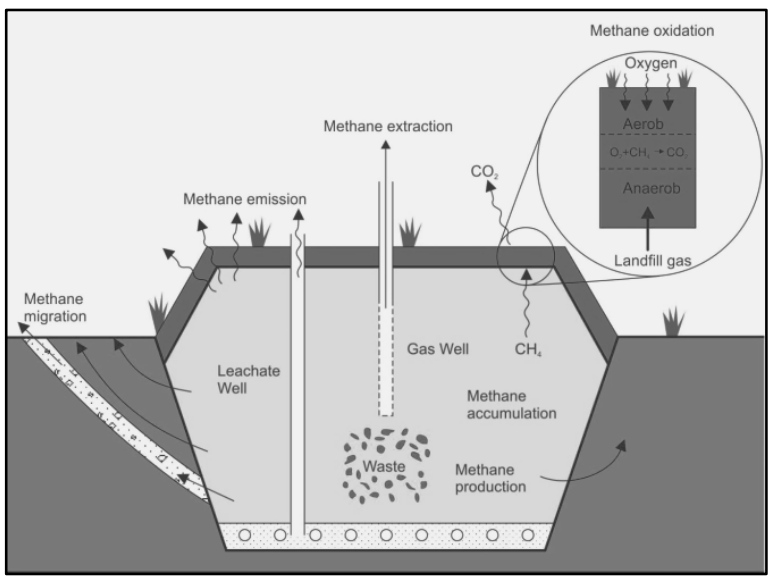

812 Fig. 1. Conceptual model for the landfill's $\mathrm{CH}_{4}$ mass balance and $\mathrm{CH}_{4}$ distribution. Modified 813 from Scheutz et al. (2009).

814 


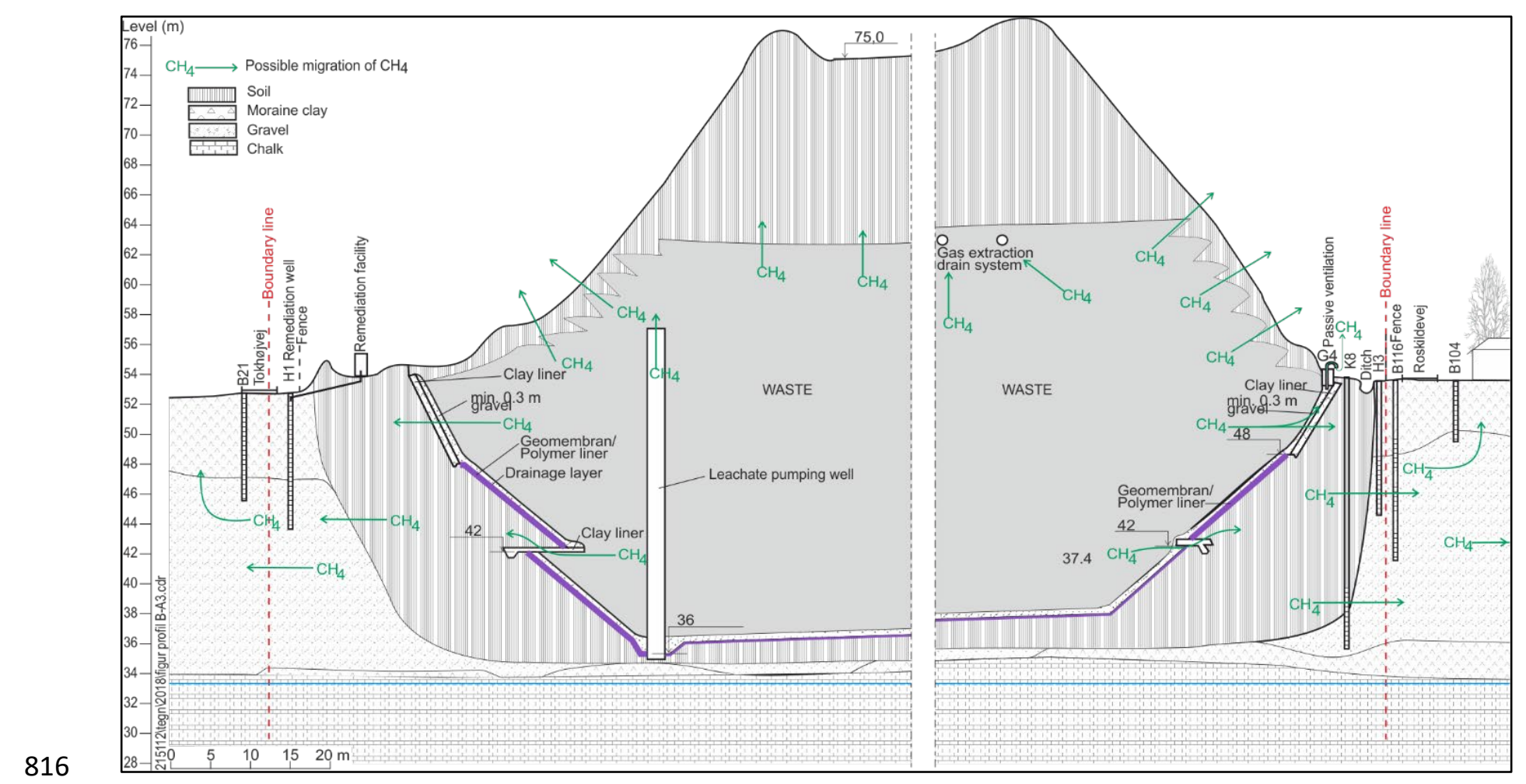

817 Fig. 2. Cross-section of Hedeland landfill. The middle of the figure has been removed. Note

818 that the scale is not the same in the vertical and lateral directions. 


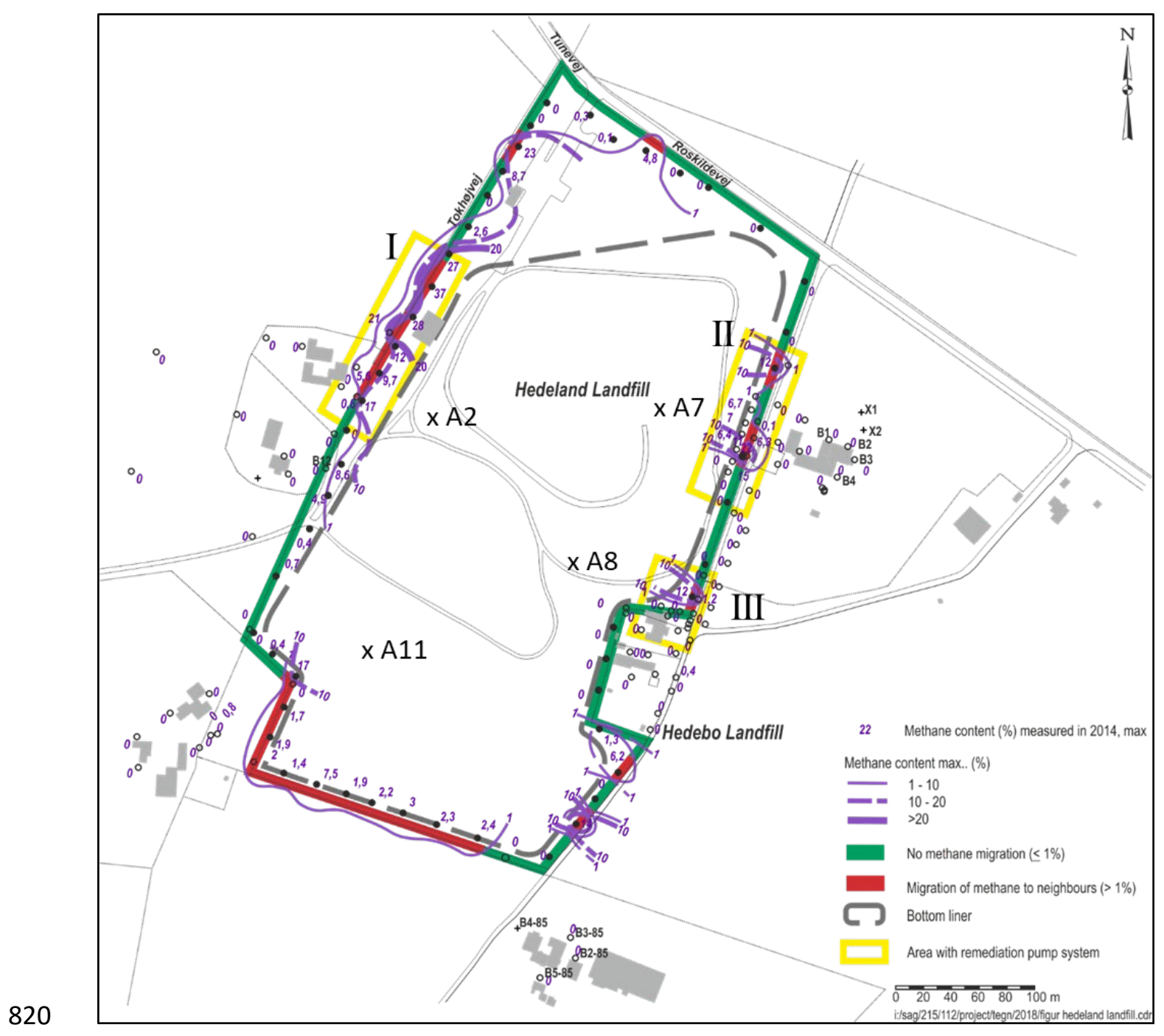

821 Fig. 3. Areas along the perimeter of the landfill with elevated levels of $\mathrm{LFG}\left(>1 \mathrm{vol} . \% \mathrm{CH}_{4}\right)$.

822 Areas in yellow boxes have remediation pumps protecting against migrating LFG, named I, II

823 and III. A2, A7, A8 and A11 indicates the location of the pumping test wells used in the

824 calculation of $\mathrm{CH}_{4}$ generation rates and the $\mathrm{CH}_{4}$ oxidation in the lateral migrating LFG. 


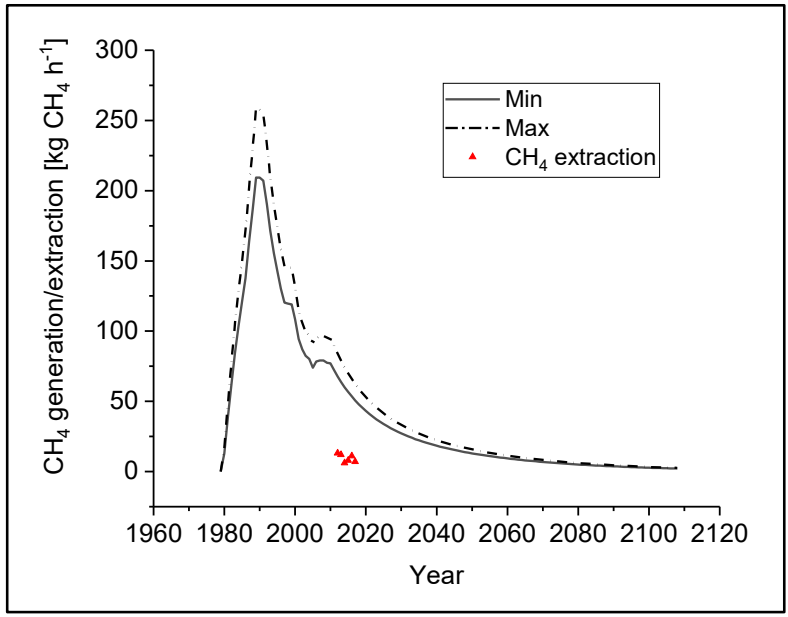

827 Fig. 4. Gas generation modelling using Afvalzorg and the annual average $\mathrm{CH}_{4}$ extraction rate 828 for 2013-2015. Generation is based on disposed waste amounts and composition as shown in 829 Table SM1 in the Supplementary Material.

830

831 


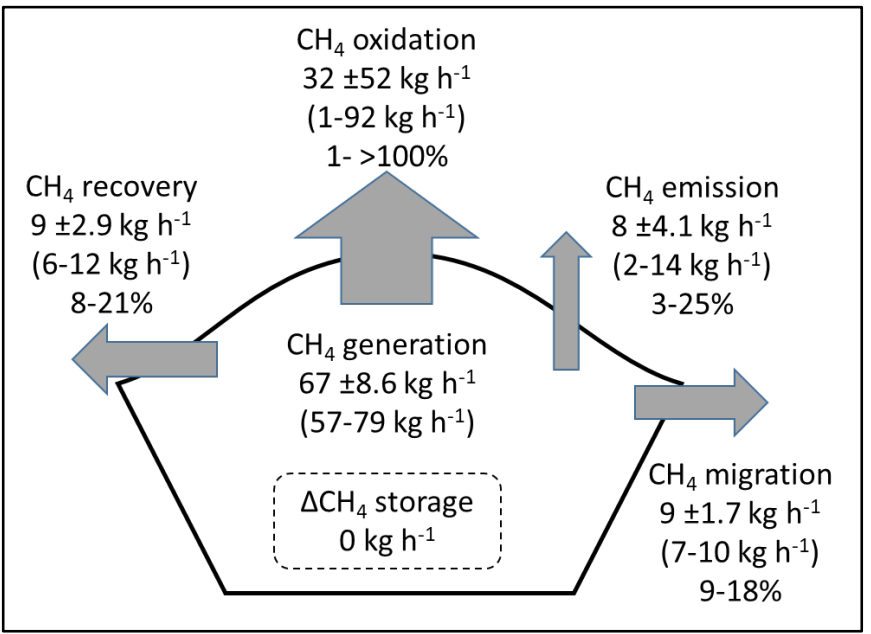

834

835 Fig. 5. Methane mass balance for Hedeland landfill. Lateral $\mathrm{CH}_{4}$ migration includes $\mathrm{CH}_{4}$

836 oxidised in the soil compartment in the area between the side liner and the monitoring wells.

837

838 